\title{
Teaching Video NeuroImages: Propriospinal myoclonus as a sequela of Guillain-Barré syndrome
}

Janis R. Bedarf, MD, Michael Nelles, MD, Jens Reimann, MD, Sebastian Paus, MD, and Julian Zimmermann, MD

Neurology ${ }^{\circledR}$ 2018;91:e297-e299. doi:10.1212/WNL.0000000000005827
Correspondence

Dr. Bedarf

Janis.bedarf@ukbonn.de

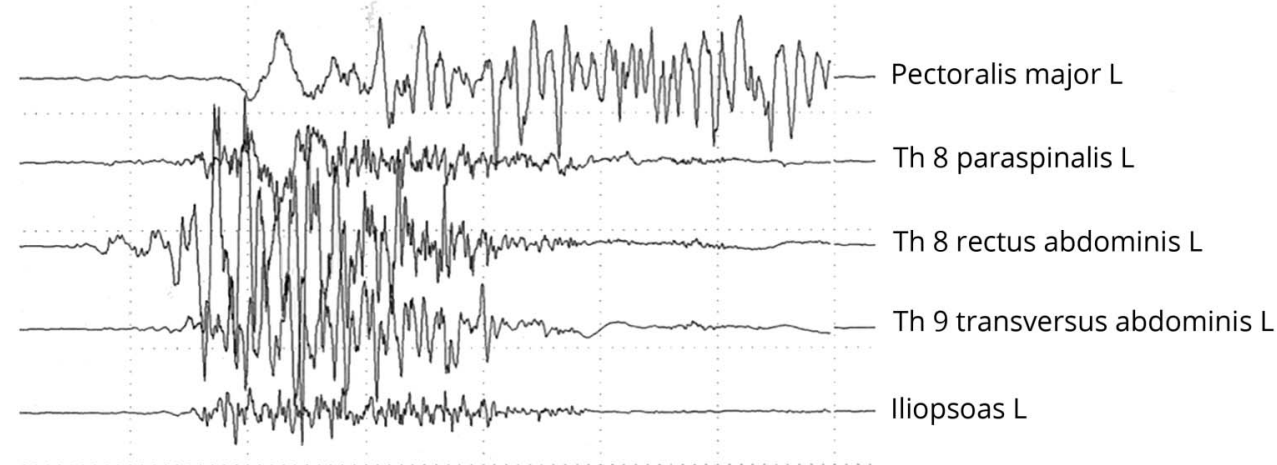

A previously healthy 27-year-old woman developed Guillain-Barré syndrome (GBS) with severe tetraplegia, requiring immunoglobulins. During remission, nonrhythmic, stimulussensitive abdominal jerks, propagating to the hips, appeared, worsening in supine position. Surface EMG confirmed propriospinal myoclonus (PSM) ${ }^{1}$ originating from Th8 (figure 1 and video). Myoclonus ceased with levetiracetam. Normal backward averaging, somatosensory evoked potentials, and absent Bereitschaftspotential argued against cortical or functional origins.

PSM is mainly based on myelon lesions. ${ }^{1}$ Occurrence as a sequela of GBS is rare, though myoclonus through radiculitis was described before. ${ }^{2}$ Although spinal imaging was within normal range (figure 2), ephaptic transmission following segmental inflammatory demyelination is the likely cause here.

\section{Author contributions}

Janis Rebecca Bedarf: study concept and design, acquisition of data, analysis and interpretation of data, manuscript preparation. Michael Nelles: acquisition of data, analysis and interpretation of data, critical revision of manuscript for intellectual content. Jens Reimann: analysis and interpretation of data, critical revision of manuscript for intellectual content. Sebastian Paus: analysis and interpretation of data, critical revision of manuscript for intellectual content. Julian Zimmermann: study concept and design, critical revision of manuscript for intellectual content.
Propagation pattern of propriospinal myoclonus, recorded by surface multichannel EMG of left-sided muscles. Myoclonic jerks have a duration of 200-400 ms. Note the first jerk of the rectus abdominis muscle, driven by the Th8 myelomere (myoclonic generator), followed by a typical rostral and caudal spread involving the iliopsoas and pectoralis muscles.

\section{MORE ONLINE}

\section{- Video}

\section{$\rightarrow$ Teaching slides}

links.lww.com/WNL/A583 

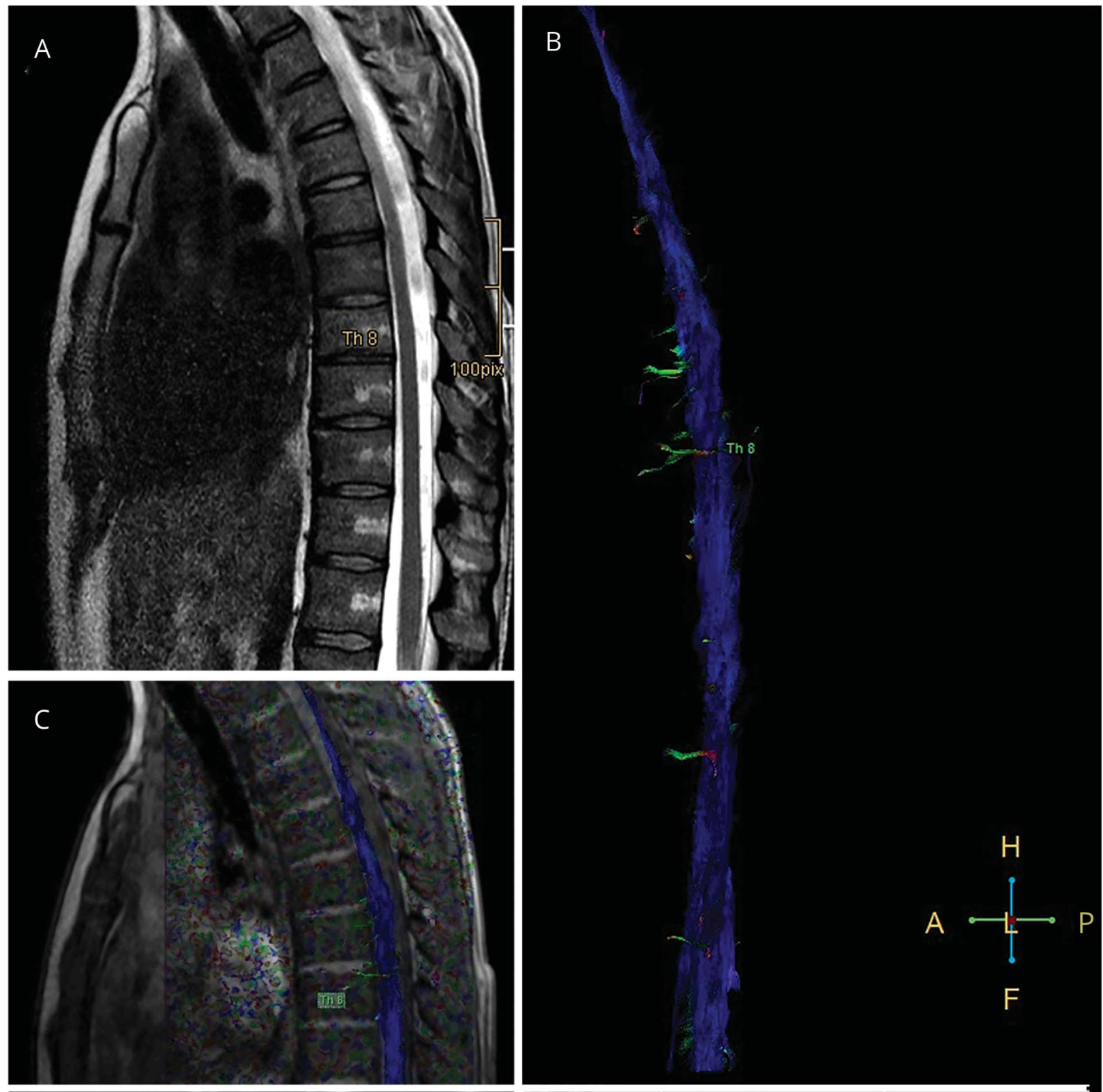

\begin{tabular}{|l|c|c}
\hline ROI name & FA ( \pm SD) & ADC $\left(\mathbf{1 0}^{-3} \mathbf{m m}^{2}, \pm \mathbf{S D}\right)$ \\
\hline Th $4 / 5$ & $0.379 \pm 0.188$ & $2.102 \pm 0.942$ \\
\hline Th 5 & $0.444 \pm 0.191$ & $2.191 \pm 0.901$ \\
\hline Th $6 / 7$ & $0.371 \pm 0.184$ & $2.231 \pm 1.047$ \\
\hline Th 8 & $0.263 \pm 0.128$ & $2.514 \pm 1.355$ \\
\hline Th 9 & $0.388 \pm 0.250$ & $2.609 \pm 1.650$ \\
\hline Th $10 / 11$ & $0.409 \pm 0.300$ & $2.905 \pm 2.050$ \\
\hline Th 12 & $0.320 \pm 0.157$ & $2.919 \pm 1.621$
\end{tabular}

T2-weighted sagittal (A) and axial (D) spinal cord MRI without focal pathology at Th8, and spinal diffusion tensor imaging with fiber tracking (B, C) without microstructural abnormalities. $\mathrm{FA}=$ fractional anisotropy values were lowest within segment Th8, compatible with an altered axonal integrity $(B) ; A D C=$ apparent diffusion coefficients were normal. $\mathrm{ROI}=$ region of interest. 


\section{Study funding}

No targeted funding reported.

\section{Disclosure}

J. Bedarf was supported by research support by the PD Fonds Deutschland gGmbH. She received travel grants and honoraria for talks for Ipsen Pharma and Merz Pharmaceuticals. M. Nelles reports no disclosures relevant to the manuscript. J. Reimann serves as an associate editor for $B M C$ Neurology. S. Paus served on scientific advisory boards for Ipsen Pharma and Merz Pharmaceuticals. He received research support and honoraria for talks for Ipsen Pharma and
Merz Pharmaceuticals. J. Zimmermann received research support by the B. Braun foundation. He served on scientific advisory boards for Bayer Healthcare, Novartis, Merck, and Roche and received travel grants from Biogen, Sanofi Genzyme, TEVA, and Merz Pharmaceuticals. Go to Neurology. org/ $\mathrm{N}$ for full disclosures.

\section{References}

1. Roze E, Bounolleau P, Ducreux D, et al. Propriospinal myoclonus revisited: clinical, neurophysiologic, and neuroradiologic findings. Neurology 2009;72: 1301-1309.

2. Miki Y, Tomiyama M, Ueno T, et al. Radicular myoclonus in a patient with GuillainBarré syndrome. Intern Med 2012;51:2021-2023. 


\section{Neurology}

\section{Teaching Video NeuroImages: Propriospinal myoclonus as a sequela of Guillain-Barré syndrome}

Janis R. Bedarf, Michael Nelles, Jens Reimann, et al.

Neurology 2018;91;e297-e299

DOI 10.1212/WNL.0000000000005827

This information is current as of July 16, 2018

\section{Updated Information \&} Services

References

Permissions \& Licensing

Reprints including high resolution figures, can be found at: http://n.neurology.org/content/91/3/e297.full

This article cites 2 articles, 1 of which you can access for free at: http://n.neurology.org/content/91/3/e297.full\#ref-list-1

Information about reproducing this article in parts (figures,tables) or in its entirety can be found online at:

http://www.neurology.org/about/about_the_journal\#permissions

Information about ordering reprints can be found online:

http://n.neurology.org/subscribers/advertise

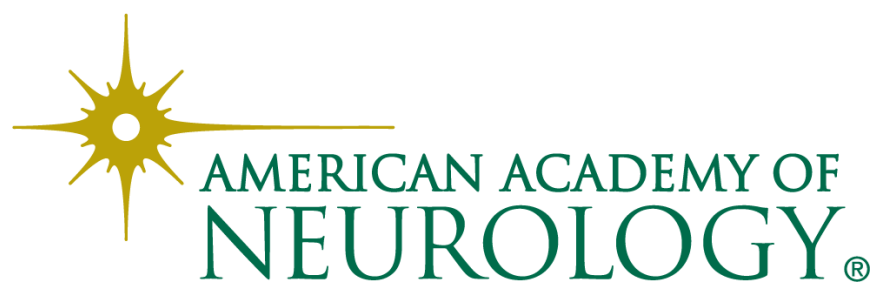

